\title{
A Review and Comparison on Recent Optimization Methodologies for Diesel Engines and Diesel Power Generators
}

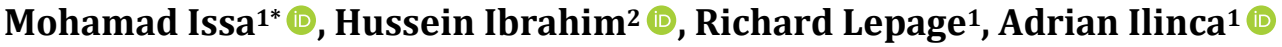 \\ ${ }^{1}$ Laboratory of Wind Energy Research, Université du Québec à Rimouski, Rimouski, Canada \\ ${ }^{2}$ Technological Institute of Industrial Maintenance, Sept-Iles, Canada \\ Email: ^missa@imq.qc.ca, Hussein.Ibrahim@itmi.ca, Richard_lepage01@uqar.ca, Adrian_ilinca@uqar.ca
}

How to cite this paper: Issa, M., Ibrahim, H., Lepage, R. and Ilinca, A. (2019) A Review and Comparison on Recent Optimization Methodologies for Diesel Engines and Diesel Power Generators. Journal of Power and Energy Engineering, 7, 31-56. https://doi.org/10.4236/jpee.2019.76003

Received: May 12, 2019

Accepted: June 23, 2019

Published: June 26, 2019

Copyright $\odot 2019$ by author(s) and Scientific Research Publishing Inc. This work is licensed under the Creative Commons Attribution-NonCommercial International License (CC BY-NC 4.0). http://creativecommons.org/licenses/by-nc/4.0/

\begin{abstract}
The electrical instability that frequently distinguishes the isolated networks and depends on diesel generators to supply their energy requirements leads to an operation of the diesel generator in a transient dynamic condition and/or at low loads. In addition, extended operation of the diesel generator at partial load develops the condensation of combustion residues on the engine cylinder walls, which, after a certain time, increases friction, reduces the efficiency of the equipment and increases its fuel consumption. On the other hand, recent regulatory changes have led to ever more stringent and evolving emission standards. Among these, the International Maritime Organization (IMO) and the Environmental Protection Agency (EPA) have implemented emission standards in order to reduce exhaust gas emitted by marine diesel engines. To phase lower emission engines as soon as possible, a Tier system was adopted. This paper presents a literature review of existing technologies available to optimize the energy performance of diesel engines and diesel generators in order to reduce the cost of electricity, to increase the diesel engine efficiency and to decrease their fuel consumption and greenhouse gases (GHG) emissions. The proposed optimization methodologies are based on the application of Pre-treatment, Internal treatment and Post-treatment technologies for diesel engines and on the application of mechanical and electrical technologies for diesel power generators (DPGs). The list of references given at the end of the paper should offer aids for students and researchers working in this field.
\end{abstract}

\section{Keywords}

Diesel Engine, Diesel Generator, Greenhouse Gas, Tier System, Energy

Efficiency, MARPOL Annex VI, Isolated Communities, Off-Grid 


\section{Introduction}

Statistics Canada reported in 2016 that 113,604 people live in the north [1] and rely on diesel generators (DGs) to meet their electricity requirements. In addition, mining facilities, telecommunications infrastructure (cellular, microwave, optical, etc.) and islands such as Anticosti and Iles-de-la-Madeleine are not connected to the main grids and depend on diesel fuel, which is relatively inefficient, expensive and responsible for emission of large amounts of greenhouse gas emissions [2]. Furthermore, in the context of electricity production in these remote areas, the use of DG's alone or in hybridization with renewable energy sources, faces many technical problems. Indeed, the electrical instability that often characterizes the isolated networks, due to the fluctuating character of renewable resources and the high variability in the load profile, lead to an operation of the diesel generator in a transient dynamic condition and/or at low loads. In addition, extended operation of the DG at low levels of charge develops the condensation of combustion residues on the engine cylinder walls, which, after a certain time, increases friction, reduces the efficiency of the equipment and increases its fuel consumption. One way to solve this problem and to eliminate these deposits is to operate the engine at a higher speed until the operating temperature is attained. According to [3], using DPGs with weak operating factors increases wear and fuel consumption. This results in the appearance of several phenomena, including icing, polishing and wet stacking. For these reasons, DPG's supplying autonomous networks are not optimal and should be improved:

- In terms of energy: the majority of DGs are oversized and it is recognized that the use of diesel generators under low load factors is very harmful to them in terms of wear and causes high fuel consumption. This is mainly due to an inadequate viscosity of the lubricating oil due to a lack of thermal energy released by engine combustion [4]. This lack of viscosity degrades the lubrication quality of the camshaft bearings and the crankshaft of the engine. The consequence of this wear is directly related to the fuel consumption, which increases during the nominal load. In general, prolonged operation of the DGs under light loads, favors the condensation of the combustion residues on the cylinder walls, which, at the end of a certain time, increases the friction, decreases the efficiency of the engine and increases fuel consumption per kilowatt-hour produced. The objective at this level is therefore to maintain the generator utilization factor greater than $30 \%$.

- Economically: DGs, while relatively cheap to purchase, are generally expensive to operate and maintain, particularly at the partial load, because of the high price of fuel delivered to isolated sites [5]. Thus, since the price of diesel fuel is very dependent on the mode of transport used, it is the transport difficulties and the particularities of delivery, which make this cost vary and further increase the cost of exploitation of the diesel generators. For example, the cost of the kWh produced in the localities accessible only by air is gener- 
ally higher than that produced in those accessible by boat or by land. In Quebec, the average cost of generating electricity from diesel in the last decades was more than $40 / \mathrm{kWh}$ in stand-alone grids, while the average price of electricity sales was established, as in the aggregate Quebec, at about 6/kWh [6].

- In terms of the environment: in addition to being non-optimal and expensive, the operation of DGs in autonomous networks has significant environmental impacts [7] [8]. It contaminates local air and soil (old and rusty generators) and contributes greatly to the emission of GHGs. In total, the GHG emissions resulting from the use of generators are estimated at 140,000 tons per year for the subscribers of the Canadian and Quebec independent networks. This quantity of emissions is equivalent to the quantity of GHG emitted by 35,000 cars during a year [9]. The fact that the exploitation of these DGs is not optimal and very expensive, it was necessary to find solutions to reduce operating deficits by favoring alternatives based on different techniques such as mechanical, electrical and ecological solutions.

On the other hand, even though pollution from ship's exhaust gases represents only $3 \%$ to $4 \%$ of global pollution, the IMO and EPA have adopted strict new standards in order to reduce pollutant emissions including nitrous oxides $\left(\mathrm{NO}_{\mathrm{x}}\right)$ and Sulphur oxides $\left(\mathrm{SO}_{\mathrm{x}}\right)$ from marine diesel engines. The new reform to the maritime pollution (MARPOL) annex VI convention adopted in 1997 includes the establishment of emission control areas (ECAs) to scale down emissions in specified sea zones with a gradual reduction in emissions of $\mathrm{NO}_{\mathrm{X}}, \mathrm{SO}_{\mathrm{X}}$ and particulate matter (PM) [10]. Since then, several measures have been taken into consideration. A tier system has been adopted to reduce $\mathrm{NO}_{\mathrm{x}}$ levels, while $\mathrm{SO}_{\mathrm{x}}$ will be reduced from current $3,50 \%$ to $0,50 \%$ beginning from 1 January 2020 and PM has been reduced to $0,10 \%$ since January 2015 . In particular, the fundamental strategy $\mathrm{NO}_{\mathrm{x}}$ limitations for diesel engines (DE's) are tiered as indicated in Figure 1, while Table 1 summarizes the regulatory requirements to reduce ship emissions of Sulphur oxides for ship categories 1, 2 and 3 [11].

The structure of the present article is as follows. Section 2 presents the state of art of DE's optimization using Pre-treatment, Internal-Treatment and Post-treatment technologies, while DPGs optimization relies on mechanical and electrical technologies. Section 3 analyzes the advantages and disadvantages of these technologies (benefits and limitations), while Section 4 provides a preliminary conclusion of our study and a perspective for future work.

\section{State of Art}

In this section, we present the different technologies and solutions available to optimize the efficiency of DEs and DPGs and reduce their emissions of greenhouse gases (GHGs). Figure 2 shows the global diagram of available technologies for DE optimization while Figure 3 shows the recent methodologies applied for DPG optimization using electrical and mechanical technologies. 
Table 1. Low sulphur phase-in dates [11].

\begin{tabular}{cccccc}
\hline \multirow{2}{*}{$\begin{array}{c}\text { Starting year } \\
\left(\text { January } 1^{\text {st }} \text { ) }\right.\end{array}$} & Oceans & $\begin{array}{c}\text { Emission } \\
\text { Control Areas }\end{array}$ & $\begin{array}{c}\text { EU } \\
\text { Ports }\end{array}$ & $\begin{array}{c}\text { California } \\
\text { Coastal }\end{array}$ & $\begin{array}{c}\text { Category 1 \& 2 } \\
\text { Ships }\end{array}$ \\
\hline 2010 & $4.5 \%$ & $1.0 \%$ & $0.1 \%$ & $0.5 \%{ }^{*}$ & $0.05 \%$ \\
2012 & $3.5 \%$ & $1.0 \%$ & $0.1 \%$ & $0.1 \%$ & $0.0015 \%$ \\
2015 & $3.5 \%$ & $0.1 \%$ & $0.1 \%$ & $0.1 \%$ & $0.0015 \%$ \\
$2020-(2025)^{* *}$ & $0.5 \%$ & $0.1 \%$ & $0.1 \%$ & $0.1 \%$ & $0.0015 \%$ \\
\hline
\end{tabular}

0, 5\%*: Marine Gas Oil, or 0, 1\% Marine Diesel Oil. (2025)**: Implementation of Oceans limit at 0,5\% sulphur.

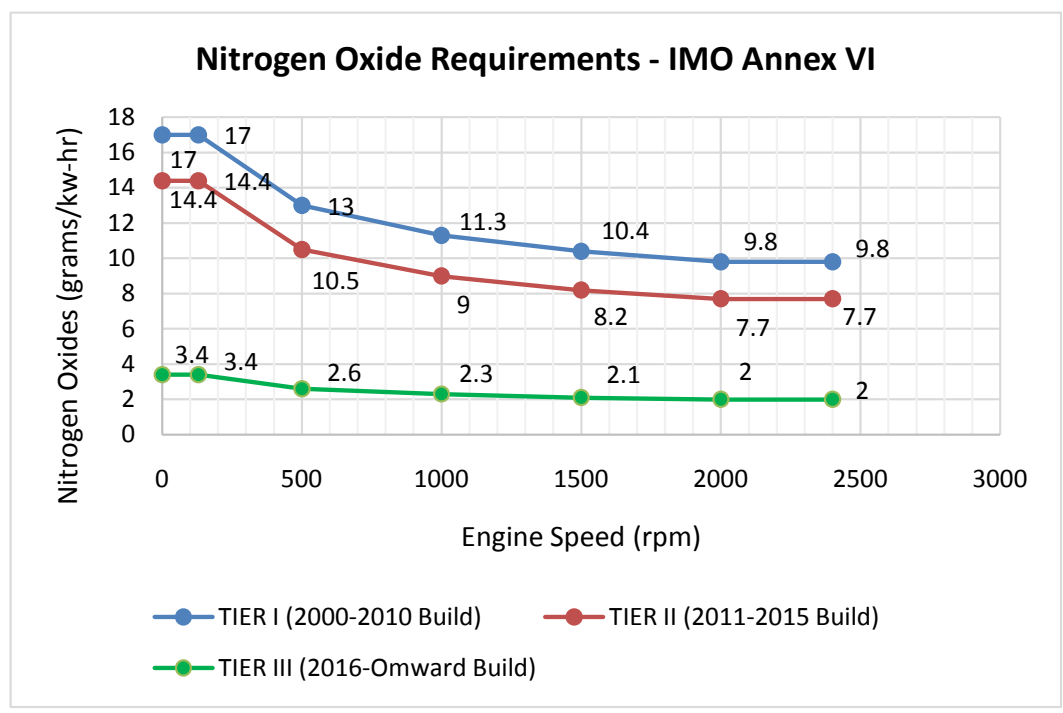

Figure 1. IMO Annex VI TIER nitrous oxides requirements [11].

DIESEL ENGINES OPTIMIZATION
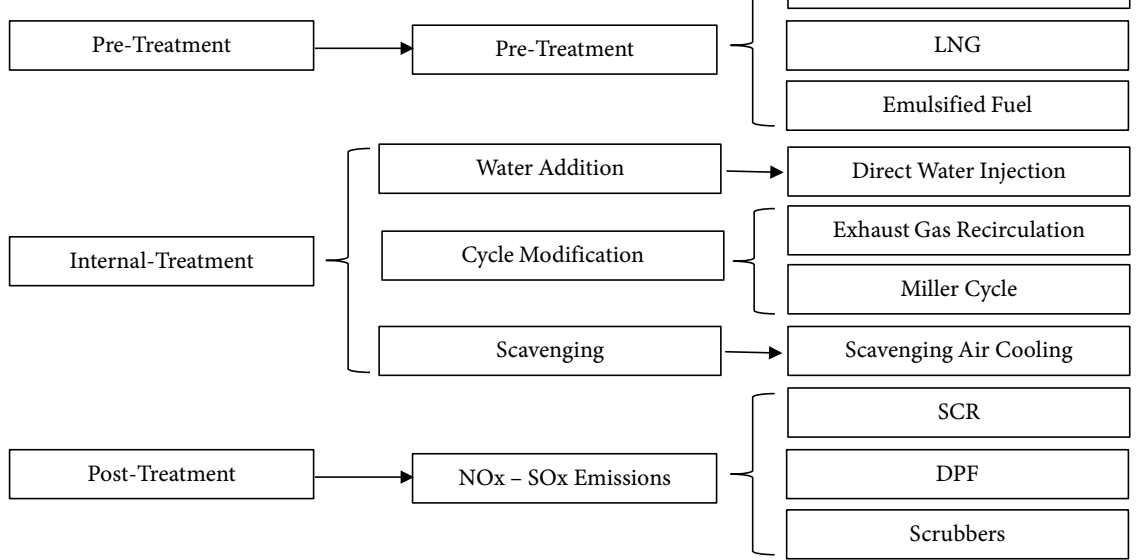

Figure 2. Optimization of the DE using pre-treatment, internal-treatment and post-treatment solutions. 


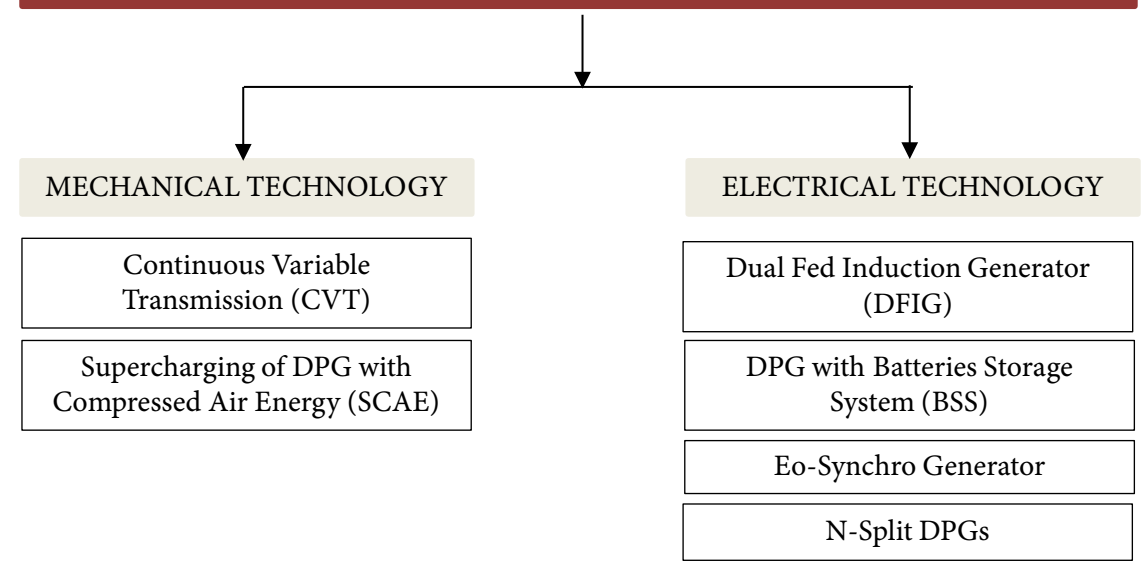

Figure 3. Optimization of the DPG mechanical and electrical technologies.

DE's optimization can be achieved using one of the three methods mentioned in Figure 2, such as pre-treatment, internal-treatment or post-treatment technologies. However, most of these technologies do not have a significant impact on fuel consumption reduction but are very effective in reducing $\mathrm{SO}_{\mathrm{X}}, \mathrm{NO}_{\mathrm{x}}$ and $\mathrm{PM}$ by over of $80 \%$. On the other hand, mechanical and electrical technologies applied to DPG's have a significant impact on fuel consumption and GHG's reduction. Some of these technologies can be considered for remote areas, while others are technically restricted. Below, the literature review of state-of-the-art technologies of DE's and DPG's optimization.

\subsection{Diesel Engine Optimization Using Pre-Treatment Solutions}

Pre-treatment methodology is based on the use of substitute fuel such as methanol and liquified natural gas(LNG), which are characterized by their low Sulphur content, allowing a reduction of $\mathrm{SO}_{\mathrm{x}}, \mathrm{NO}_{\mathrm{x}}$ and $\mathrm{PM}$ emissions. In addition, methanol was a major research topic in the $80 \mathrm{~s}$ and $90 \mathrm{~s}$ for transportation application [12] and because of its availability, production and application in fuel cell cars [13] [14] [15] [16]. However, methanol presents challenges for its adaptation on DE's making auto ignition hard due to the low methanol cetane number [17]. Emissions from DE with different fuel were compared and analyzed by Wang et al. and have shown reduction of $\mathrm{NO}_{\mathrm{x}}$ and $\mathrm{PM}$ but an increase in carbon monoxide (CO) and Hydrocarbon (HC) emissions from the methanol-fueled engines. The most recent attraction is the combination of diesel and methanol, which Wang W. et al. [17] proposed a diesel/methanol compound combustion (DMCC). By using a DMCC, engine will operate on diesel alone at engine start and light loads to provide a cold starting capacity and prevent the production of aldehydes, while at medium and high loads; the engine operates on a uniform air/methanol mixture to reduce $\mathrm{NO}_{\mathrm{x}}$ and PM emissions. Figure 4 shows the impact of DMCC on $\mathrm{NO}_{\mathrm{x}}$ emissions and on the specific fuel consumption [17]. 


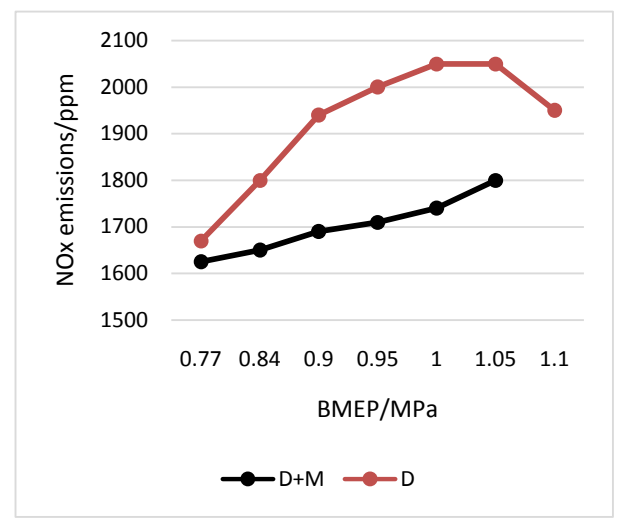

(a)

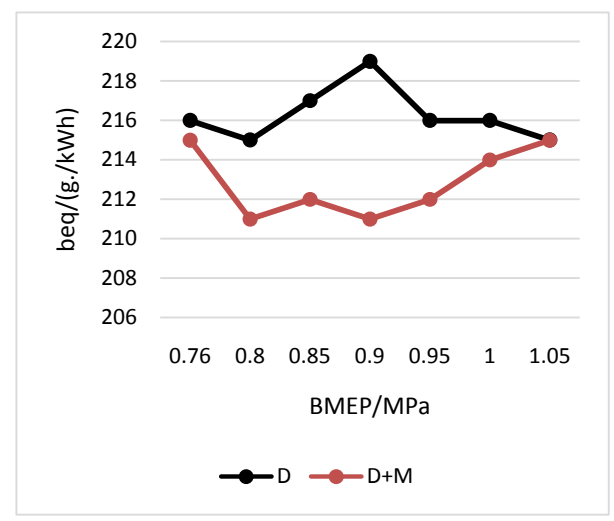

(b)

Figure 4. In (a), comparison of $\mathrm{NO}_{\mathrm{x}}$ emissions $\mathrm{D}$ for diesel turbocharged engine and $\mathrm{D}+\mathrm{M}$ for MDCC; In (b), comparison of equivalent fuel consumption [17].

According to Figure 4, there is approximately $8 \%$ reduction in NOx and $2.8 \%$ of fuel consumption when operating with MDCC. Despite its advantages, methanol increases the corrosion risk, which must be sufficiently upgraded to fuel tanks. On the other hand, LNG seems to be an attractive, promising and technically suitable option to satisfy with the regulations on air pollution [17]. LNG has the advantage of reducing $\mathrm{SO}_{\mathrm{x}}, \mathrm{NO}_{\mathrm{x}}, \mathrm{CO}_{2}$ and $\mathrm{PM}$ compared to the use of a heavy fuel oil (HFO) by 98\%, 86\%, 11\% and 96\% respectively [18], Figure 5.

Moreover, LNG offers an important benefit over the current HFO in terms of the cost by about $31 \%$ per year [18]. A previous study assessed by Wärtsilä in order to evaluate the advantages of changing from HFO fueled engine equipped with a Sea scrubber to LNG fueled engine [19] has shown additional savings from the annual machinery cost (maintenance, oil lubricating, scrubber and SCR with annual capital) by an amount of $500 \$ / \mathrm{kW}$. Despite these advantages, the LNG's challenge lies in its expensive installations on the one hand and is the higher sizes of its tanks which are 4 times greater than the marine diesel oil tanks [20] on the other hand.

While the use of methanol and LNG appears to increase over the next couple of years in ECAs, emulsified fuel, which was proposed by Professor B. Hopkin- 
son, consists in mixing two entirely immiscible liquids offering the advantage for a better atomization and a better distribution of the fuel resulting in a complete combustion [21] [22]. Emulsified fuel has the advantage of reducing $\mathrm{NO}_{\mathrm{x}}$ and PM emissions by an amount of $30 \%$ and $80 \%$ respectively [23] [24].

However, it also motives corrosion of engine components and the short common of oil-water separation phenomenon [25]. Furthermore, emulsified fuel increases the fuel consumption by $2 \%-3 \%$ to achieve a same output, Figure 6 .

\subsection{Diesel Engine Optimization Using Internal-Treatment}

Generally speaking, Internal-treatment consists of a direct modification in the diesel engine. This is done by the DE manufacturers and may require modifications in the injectors design such as the use of direct water injection (DWI) and/or engine cycle such as the use of Miller cycle, exhaust gas recirculation (EGR) and/or combustion chamber such as the use of scavenge air temperature. All these technologies have a positive impact on the reduction of $\mathrm{NO}_{\mathrm{X}}$ and $\mathrm{PM}$ and can further achieve the standards set out in Annex VI of the MARPOL convention.

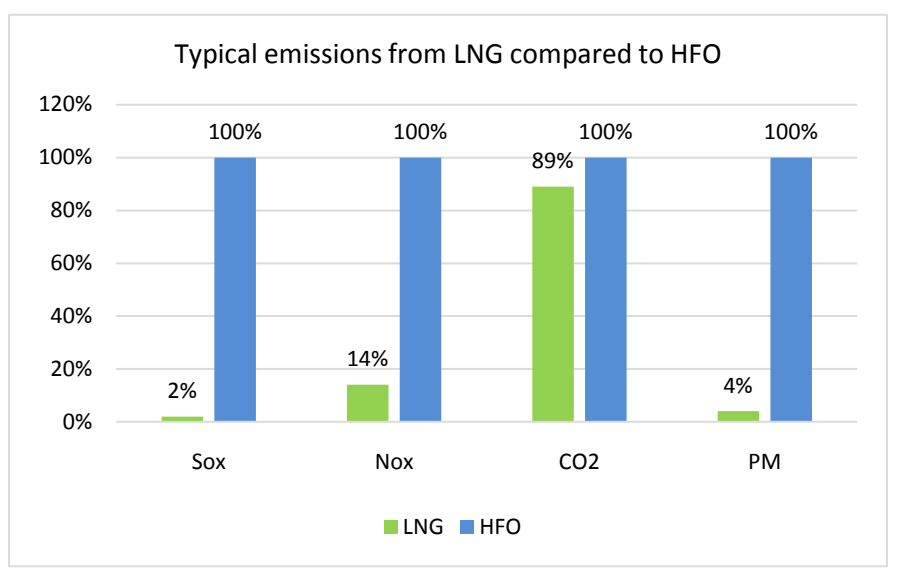

Figure 5. Relative gas emissions for LNG and HFO [18].

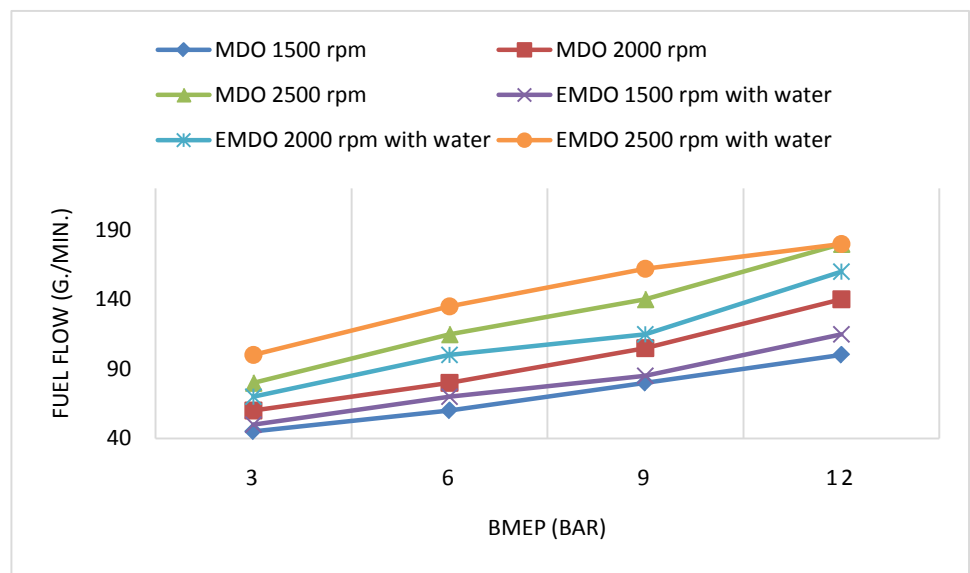

Figure 6. Comparison of fuel consumption with marine diesel oil and emulsified fuel according to rpm tested on a four-stroke-turbo-charged direct injection DE [25]. 
DWI technology uses an injector composed of two parts, one to spray water and the other to inject fuel oil [26], Figure 7. During the fuel injection phase, the water-fuel density $0.4-0.7$ high pressure water is injected into the combustion chamber and the mixture of water and combustion gas is completed, allowing a reduction of combustion temperatures and $\mathrm{NO}_{\mathrm{X}}$ emissions by up to $60 \%$ [27]. Another advantage of using this technology appears in the fact that it does not require an extra space or additional cost and can be integrated for a medium speed marine diesel engine. However, this technology can bring to lightly more fuel consumption rate by $2 \%$ approximately.

Nevertheless, Miller cycle, which was initially proposed by R. H. Miller in 1947, consist to use the Early Intake Valve Closing (EIVC) to achieve internal cooling before compression in order to reduce the compression cycle work [28].

The Miller cycle is considered as a cold cycle and allows a lower $\mathrm{NO}_{\mathrm{x}}$ emission up to $40 \%-60 \%$ and increase the efficiency of the engine [29]. Furthermore, Miller cycle can be used on four stroke marine diesel engine to complete low scavenge air temperature [30], Figure 8. By reducing the scavenge air temperature, combustion temperatures and $\mathrm{NO}_{\mathrm{X}}$ are reduced. According to [31], for each $3^{\circ} \mathrm{C}$ reduction, nitrogen oxide decreases approximatively by 1 percent.

Moreover, internal engine technology such as Exhaust Gas Recirculation (EGR) results in combustion temperature reduction and small $\mathrm{NO}_{\mathrm{x}}$ composition. It is considered as the principal technology to reduce $\mathrm{NO}_{\mathrm{X}}$ from DE. Figure 9 illustrates the schematic diagram of EGR technology [32]. The resulting combination of exhaust gas with the fresh air has a low volume calorific value, which reduces the combustion chamber temperatures, and allows $\mathrm{NO}_{\mathrm{x}}$ less formation by 40 percent and more.

It should also be noted that other technologies such as Humid Air Moisturizer (HAM) could reduce nitrogen oxides formation by up to $65 \%$. The HAM technology reposes of a moisturizer, circulating pump, heat exchanger and can require a treatment system to control the mineral content of the water [33].

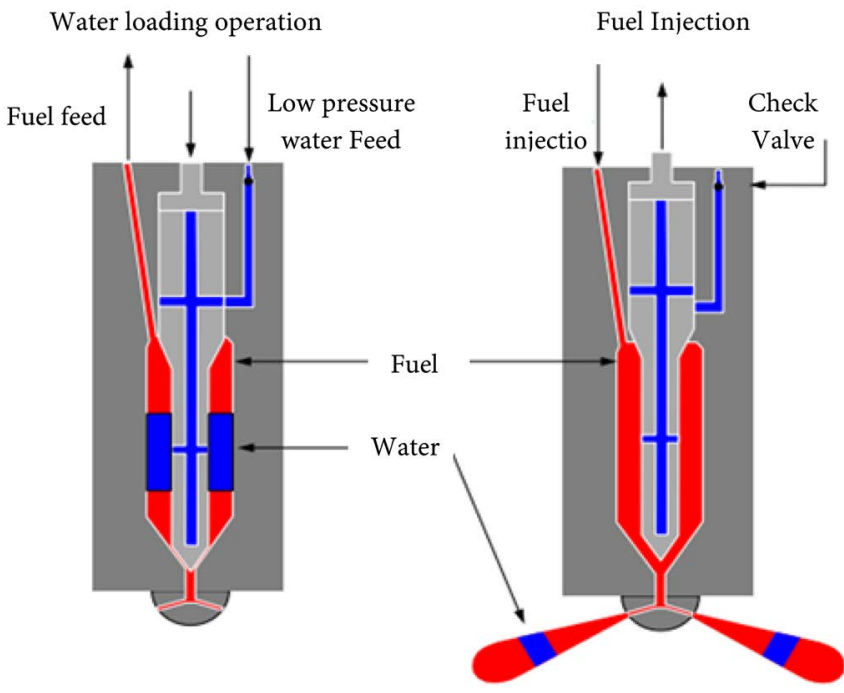

Figure 7. Operation of a classical fuel-water injection system [26]. 


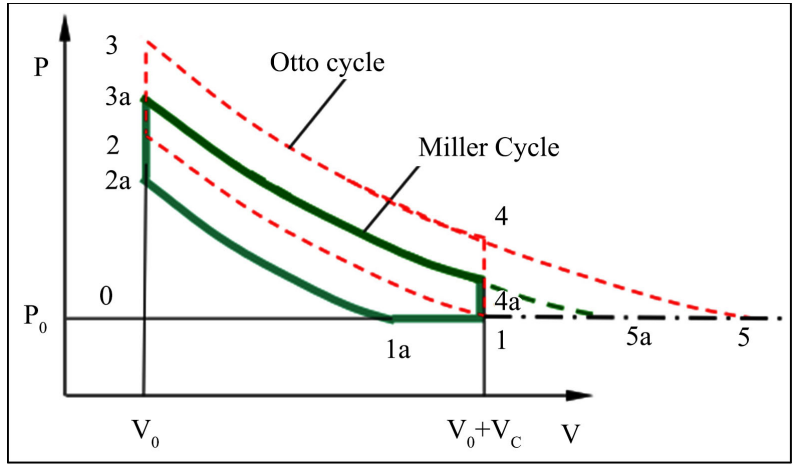

Figure 8. A comparison between Otto cycle and Miller cycle diagram [30].

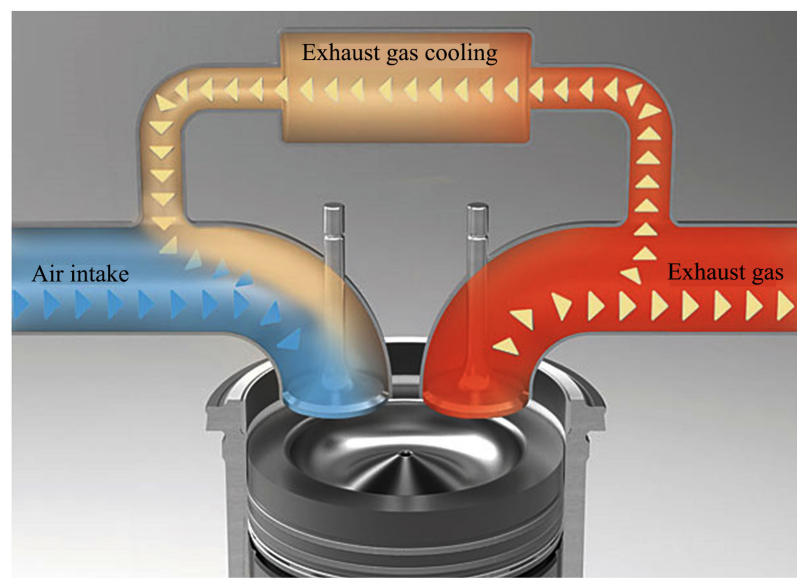

Figure 9. Schematic diagram of EGR [32].

\subsection{Diesel Engine Optimization Using Post-Treatment}

During 1994 and 2006, exhaust gas emissions regulations for heavy-duty DE's adopted by the EPA aimed attention on reducing $\mathrm{NO}_{\mathrm{x}}$ emissions. During this period, $\mathrm{NO}_{\mathrm{x}}$ emission requirements declined from $5 \mathrm{~g} / \mathrm{bhp}-\mathrm{hr}$ to 2.4 g/bhp-hr [34]. Consequently, most manufacturers of DE's have adopted the post-treatment technologies to meet $\mathrm{NO}_{\mathrm{x}}$ emissions limit. While $\mathrm{NO}_{\mathrm{x}}$ abatement relies on post-treatment technologies and/or Internal-treatment such as the EGR and Miller cycle, there is no consequence on Sulphur oxides emissions by bringing measures within the DE [35]. Currently, there is one way to minimize the $\mathrm{NO}_{\mathrm{x}}$ emissions by applying after-treatment technology such as the selective catalytic reduction (SCR), diesel particulate filter (DPF), scrubbers or using low Sulphur content fuel such as LNG, methanol and light marine fuel oil (LMFO). However, SCR has an advantage in its adaptation and does not require a modification of the engine architecture but can be subject to space restrictions. Moreover, SCR offers the largest reduction of nitrogen oxide up to 90 percent on DE's. The functioning principle is that the waste exhaust gas is combined with ammonia $\left(\mathrm{NH}_{3}\right)$ or urea before passing over a special catalyst layer at a high temperature between $300^{\circ} \mathrm{C}-400^{\circ} \mathrm{C}$, reducing the $\mathrm{NO}_{\mathrm{x}}$ to $\mathrm{N}_{2}$ and water $\left(\mathrm{H}_{2} \mathrm{O}\right)$ [36], Figure 10. 


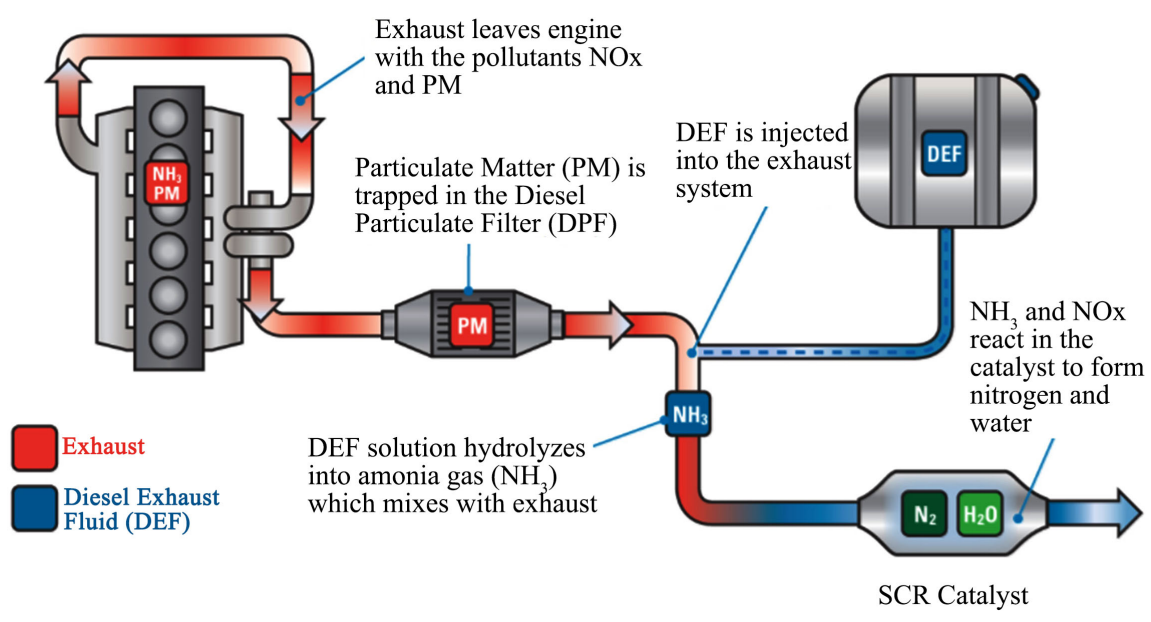

Figure 10. Illustration of the SCR system [36].

For optimal operation, engine load should be higher than $40 \%$ and exhaust gas temperature between $270^{\circ} \mathrm{C}$ and $400^{\circ} \mathrm{C}$, Figure 11 . If the temperature is below of $270^{\circ} \mathrm{C}$, ammonium sulphates can form and destroy the catalyst. If temperature exceeds $400^{\circ} \mathrm{C}$, ammonia burns rather than reacting with nitrogen oxides [37] [38].

While SCR offers up to $90 \%$ of efficiency for $\mathrm{NO}_{\mathrm{x}}$ reduction, a diesel particulate filter (DPF) is used in order to reduce the particulate matter (PM) by an amount of $80 \%$ approximately [39]. However, the captured particles will result in an increasing backpressure on the engine allowing an increase in fuel consumption. For this reason, it is therefore important to remove the captured particles using a so-called regeneration technique.

On the other hand, wet or dry-scrubbers are considered the most suitable solutions in order to reduce the $\mathrm{SO}_{\mathrm{x}}, \mathrm{NO}_{\mathrm{X}}$, and $\mathrm{PM}$ from exhaust of heavy-duty DE's. They are very effective systems, removing up to $99 \%$ and $60 \%$ abatement of $\mathrm{SO}_{\mathrm{X}}$ and $\mathrm{NO}_{\mathrm{X}}$ according to [40] [41] but they are very expensive to install and maintain [42]. Table 2 shows the performance of the Ecospec $\mathrm{CSNO}_{\mathrm{x}}$ scrubber developed for marine diesel engines industry that removes Sulphur dioxide, nitrogen dioxide and carbon dioxide all in one process, in a single system [43], while Figure 12 and Figure 13, show a schematic of wet and dry scrubbers [44].

$\mathrm{CSNO}_{\mathrm{x}}$ scrubber relies on the patented Ultra Low Frequency (ULF) wave treatment of water to remove the gases. Unlike conventional systems, the system does not require purely fresh water and a cooler to support the chemical process.

Despite their advantages, Scrubbers require frequent maintenance, and can suffer from very severe corrosion [44].

\subsection{Diesel Power Generator Optimization Using Mechanical and Electrical Technologies}

It is known that running a fixed speed DPG at a light load is harmful to the environment, consumes more fuel and leads to wet stacking phenomena [45]. To overcome this challenge, variable speed diesel engine (VSDE) offers the possibil- 
ity to adapt the speed of shaft rotation according to the applied load and allows fuel consumption to be reduced and combustion temperature to be improved. VSDE can be achieved by adopting one of two approaches, with mechanical or electrical technologies. The mechanical solution includes the integration of a continuous variable transmission (CVT), while electrical solution involves the replacement of the synchronous alternator by Eo-synchro alternator or by dual fed induction generator (DFIG) which is applied widely in wind turbine projects.

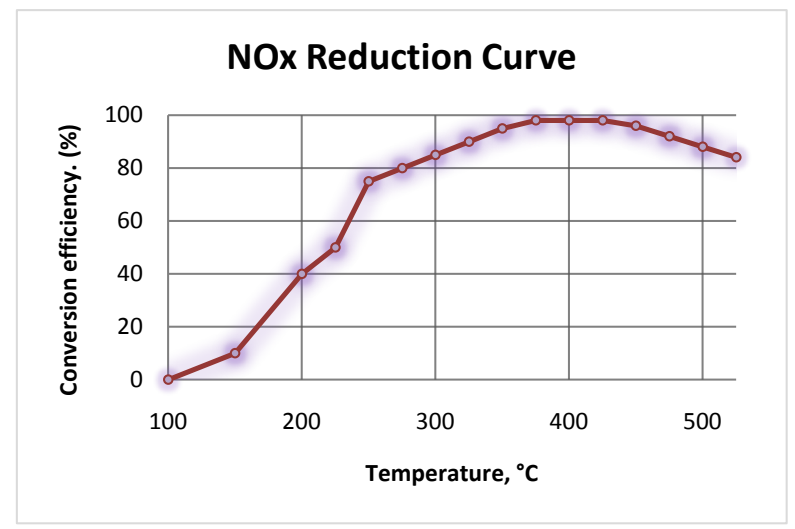

Figure 11. $\mathrm{NO}_{\mathrm{X}}$ reduction performance using SCR [38].

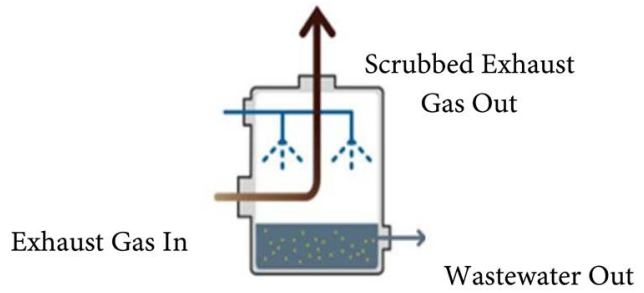

Figure 12. A schematic of wet-scrubber system. Absorbent solution is diffused over the exhaust flue gases allowing the abatement of $\mathrm{SO}_{\mathrm{x}}$ and $\mathrm{NO}_{\mathrm{x}}$ [44].

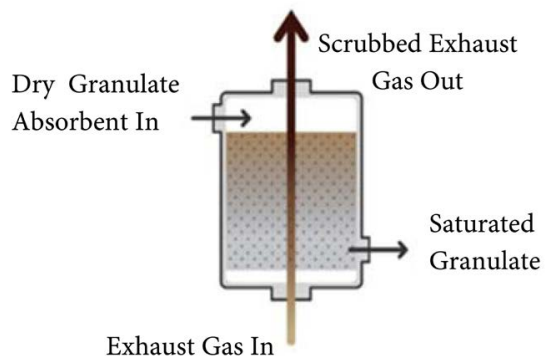

Figure 13. A schematic of dry-scrubber system. The flue gases are passed over granulate absorbent packing bed allowing the abatement of the $\mathrm{SO}_{\mathrm{x}}$ and $\mathrm{NO}_{\mathrm{x}}$ [44].

Table 2. Performance of the $\mathrm{CSNO}_{\mathrm{x}}$ scrubber system [43].

\begin{tabular}{cccc}
\hline & $\mathrm{SO}_{\mathrm{x}}$ Removal & $\mathrm{NO}_{\mathrm{x}}$ Removal & $\mathrm{CO}_{2}$ Removal \\
\hline $\mathrm{CSNO}_{\mathrm{x}}$ & $99 \%$ & $66 \%$ & $77 \%$ \\
\hline
\end{tabular}


Mechanically talking, The CVT can adjust the working speed independently of the engine speed, which in turn reduces fuel consumption and GHG's [46]. The Quebec Company CVT Corp. has incorporated a continuously variable transmission in a $125 \mathrm{~kW} \mathrm{DPG} \mathrm{set} \mathrm{in} \mathrm{order} \mathrm{to} \mathrm{optimize} \mathrm{fuel} \mathrm{consumption} \mathrm{and}$ reduce GHG emissions for the Puvurnaq power station in Alaska [47], Figure 14. Tests have shown a significant saving in terms of fuel and GHG's by an amount of $25 \%$. However, CVT Corp discloses on its website that the maximum power of the generator for which the transmission can be integrated, must not exceed $150 \mathrm{~kW}$. This can be explained in the work carried out by [46] [47] [48] that the limits of a CVT are due to losses of couples due to the use of metal belts, Figure 15, and friction between the pulley and the belt resulting in significant wear [48].

In addition, it is normally obligated to be replaced when a CVT fails. This is because individual components can be very expensive or because the specific defective component can be difficult to locate or impossible. For this reasons, electrical solutions seem more advantageous within off-grid applications.

Optimization of DPG's can also be achieved through several methodologies such as the use of compressed air produced by renewable energies to supercharge the DE [49] [50] [51] [52] [53]. Results and tests demonstrated the viability of the supercharge approach by compressed air energy and its storage (CAES) [54], which enabled a significant reduction on fuel consumption and GHG by $25 \%$. Another simpler approach, the air power assist engine (APAE), Figure 16, was proposed and tested by [55]. It consists of connecting the air storage tank to the exhaust collector and the use of 3-way valve to change the flow between the turbine and the air storage tank. The APAE shows a fuel consumption reduction up to $15 \%$ and generate a positive power by using the compressed air energy.

In addition, pneumatic overfeeding showed an increase in engine efficiency and up to $34 \%$ reduction in fuel consumption were reported in simulations with various cycles in the work of [49]-[55]. Figure 17 shows the fuel consumption reduction with different air intake pressure tested on a $5 \mathrm{~kW}$ hybrid pneumatic-diesel generator [49].

On the other hand, electrical technology such as application of Genset-Synchro alternator to a diesel engine has shown a significant fuel saving in [56] [57] [58]. The Genset-Synchro alternator is a power unit control system with a highly original approach for power generation based on an innovative alternator design [58], Figure 18. Modifications to the structure holding the stator windings are the leading principle behind the Genset-Synchro alternator where this structure now rotates freely in reference to the rotor and frame [56] [57]. An auxiliary motor, driven by a dedicated automatic controller, dictates the desired position, speed or acceleration of the stator structure. This concept ensures regular wave quality regardless of speed variations of the rotor. No energy goes through power electronic equipment as in conventional technologies [56] [57] 
[58].

However, with the Genset-Synchro concept, it becomes possible to control the synchronous speed of a 3-phase alternator by controlling the mechanical speed of the stator (control of stator speed only). A significant fuel saving up to $12 \%$ can be achieved at low loads (less than $40 \%$ ) and up to $5 \%$ at high loads (85\%), Figure 19 [57]. However, the presence of rotor brushes requires more maintenance work and the maximum power delivered by the generator is limited to $85 \%$ due to the compensator motor and electronic drive, which are powered by the same output of the generator.

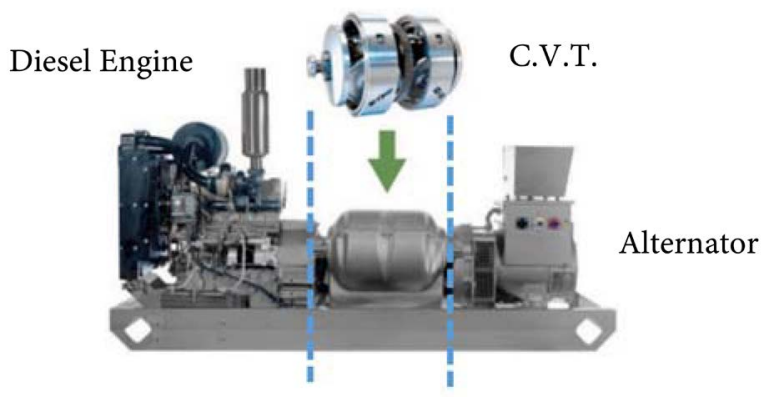

Figure 14. A $125 \mathrm{KW}$ diesel generator equipped with a CVT [47].
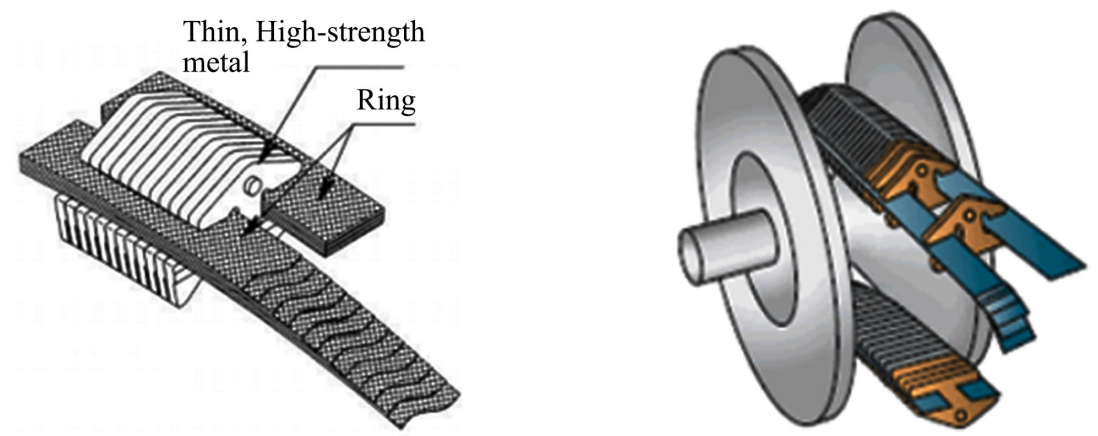

Figure 15. Metal belt design layout [48].

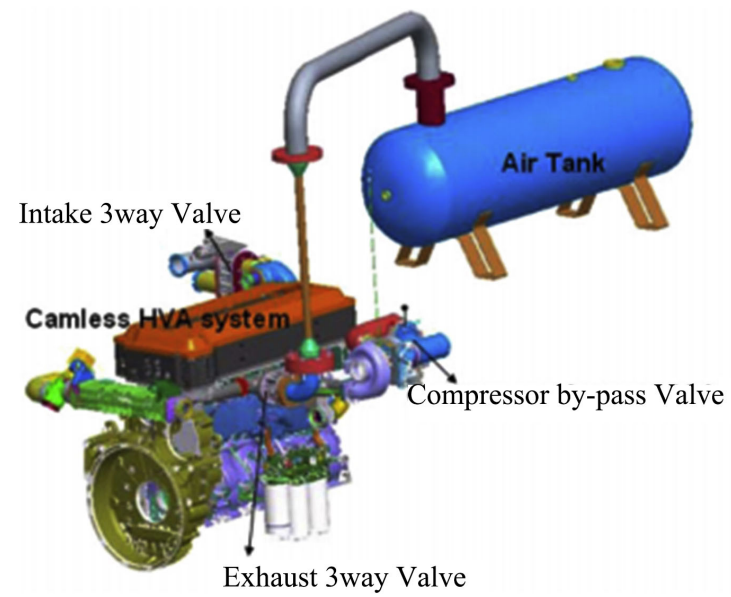

Figure 16. The air power assist engine (APAE) as proposed by Hyungsuk et al. [55]. 


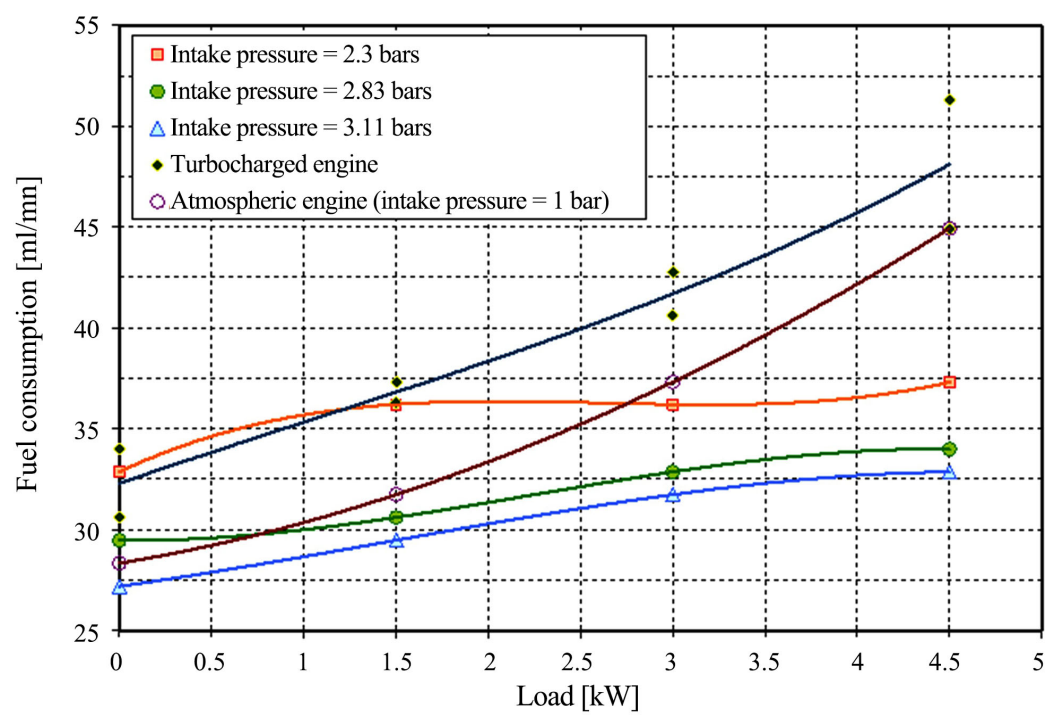

Figure 17. Comparison on fuel consumption reduction with different air intake pressure [49].

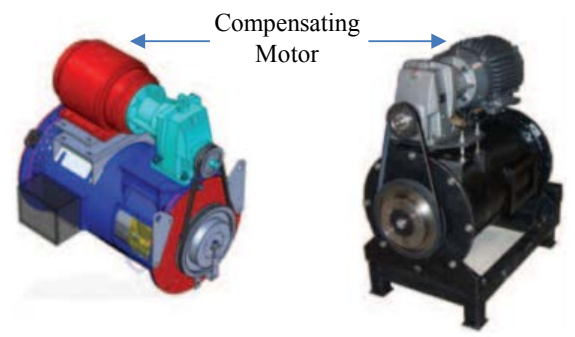

Figure 18. The concept and prototype of an $80 \mathrm{~kW}$ Genset-Synchro alternator [58].

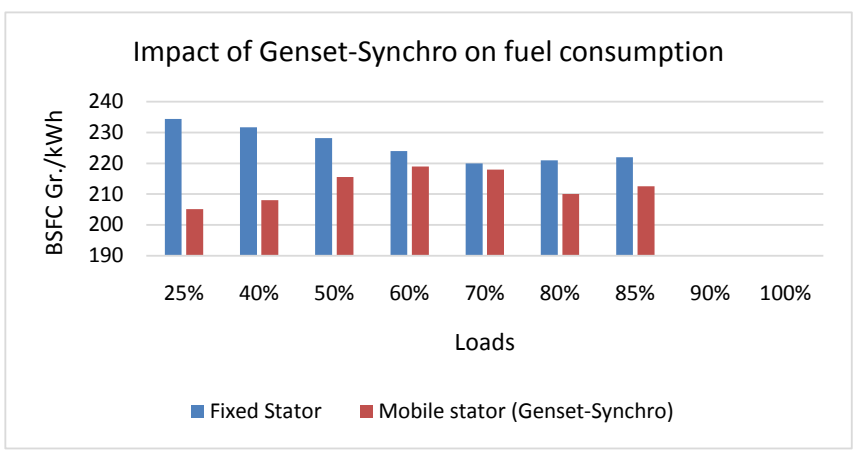

Figure 19. Impact of the Genset-Synchro alternator on fuel consumption applied to a $500 \mathrm{~kW}$ DPG [57].

Furthermore, application of DFIG in a DPG can achieve a reduction of fuel consumption and GHG's by up to $20 \%$ [59]. Another advantage lies in the use of lower power converters range of $20 \%$ of power delivered by stator at synchronous speed [60]. DFIG is built from slip-ring induction generator (SIG) and power electronic converter (PEC) placed between the stator and rotor slip rings [59] [60], Figure 20. 


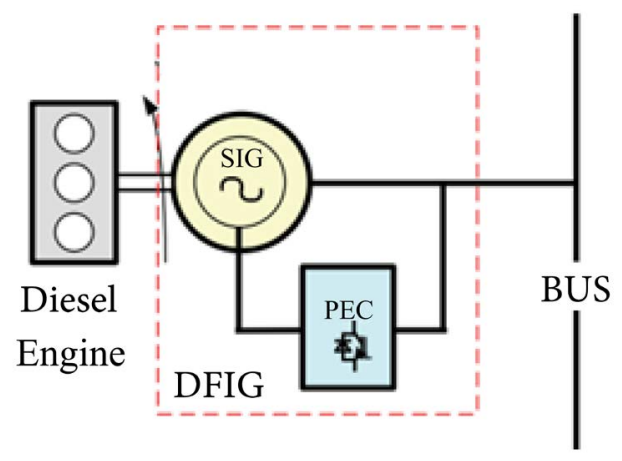

Figure 20. DFIG applied on DPG for energy saving [59].

Despite their advantages, the DFIGs present important harmonic disturbances [59] and require more maintenance due the presence of rotor brushes [59] [60] [61].

DPG optimization can also include the management of electricity generated to minimize losses to the greatest extent possible. This can be done according to two approaches such as the use of n-split DPG's or by using DPG's with storage batteries. In the first approach, it consists of using several smaller units of DPG's whose combined power output is equal to a single DPG, which would otherwise have been used [62]. The big advantage is that it permits multiple power output levels due to the multiple possible combinations of small DPG's thus avoiding the engine to operate under a partial load. Figure 21 illustrates a typical arrangement of the n-split DPGs [62].

According to the research conducted by Ayodele T.R. et al. [62] and which consist the use 3-split DPG's instead of a large sized DPG has shown an improved performance for life cycle cost (LCC), net dump energy, net $\mathrm{CO}_{2}$ emission and net fuel consumption, Figure 22.

According to Figure 22(a) and Figure 22(b), there is a reduction by $26 \%$ in LCC and a $26.5 \%$ on fuel consumption when compared to the single DPG. Moreover, Figure 22(c) and Figure 22(d) reveal that the $\mathrm{CO}_{2}$ emissions and the net dump energy of the 3-split DPG's acquired over the period of 9 years, were $27 \%$ and $85 \%$ lower versus the use of one single large sized DPG.

Finally, and to complete this literature review, application of DPG with batteries storage systems (BSS) has been the subject of researchers for different applications such as stand-alone Microgrid [63]-[68]. Figure 23 illustrates a typical plan of stand-alone Microgrid. The system contains one local and one general battery storage. The general battery storage should supply the Microgrid for long periods of time in case of emergency situations while the local battery storage is to supply the necessary power conversion parameters for short periods of time [64]. DPG'S and BSS can be combined at any time and the length of their duration work depends on the amount of fuel and batteries discharge. According to [65], realization and application of this methodology in control system allows a fuel consumption reduction for $2 \%-5 \%$ at acceleration intervals. 
Last but not least, different strategies could be investigated in the future to improve the global optimization of the DPG, such as combination of two or three technologies in order to increase efficiency of the DE and to reduce the GHG.

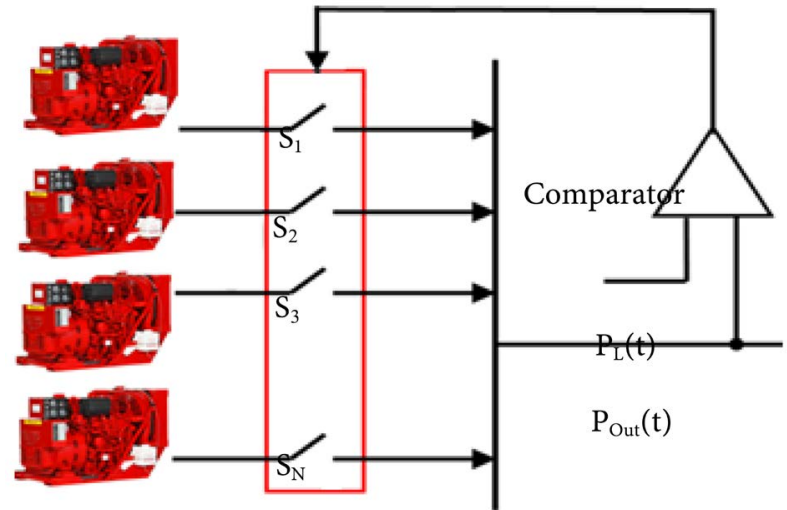

Figure 21. Control of the n-split DPGs model [62].

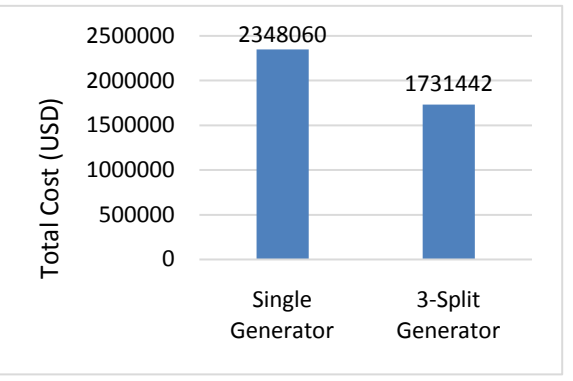

(a)

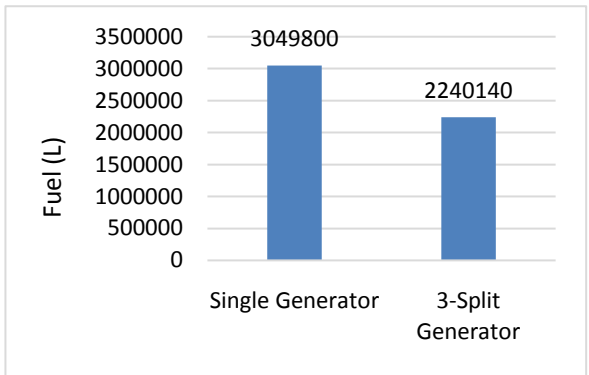

(b)

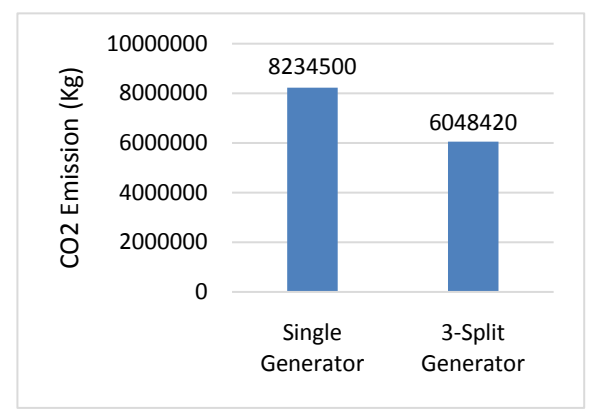

(c) 


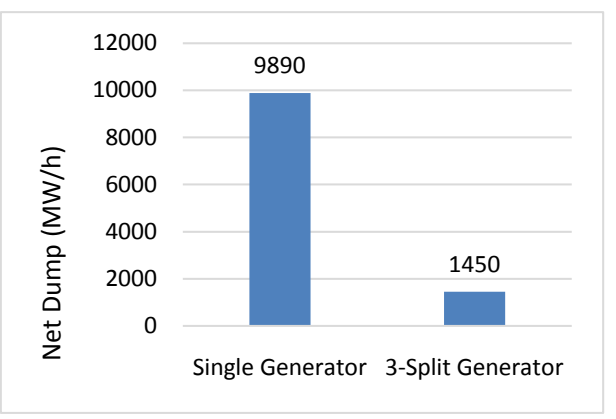

(d)

Figure 22. Comparison of the performance indices between 3-split DPG's versus a single large sized DPG [62]. (a) System LCC; (b) Fuel usage; (c) $\mathrm{CO}_{2}$ emission; (d) System dump energy.

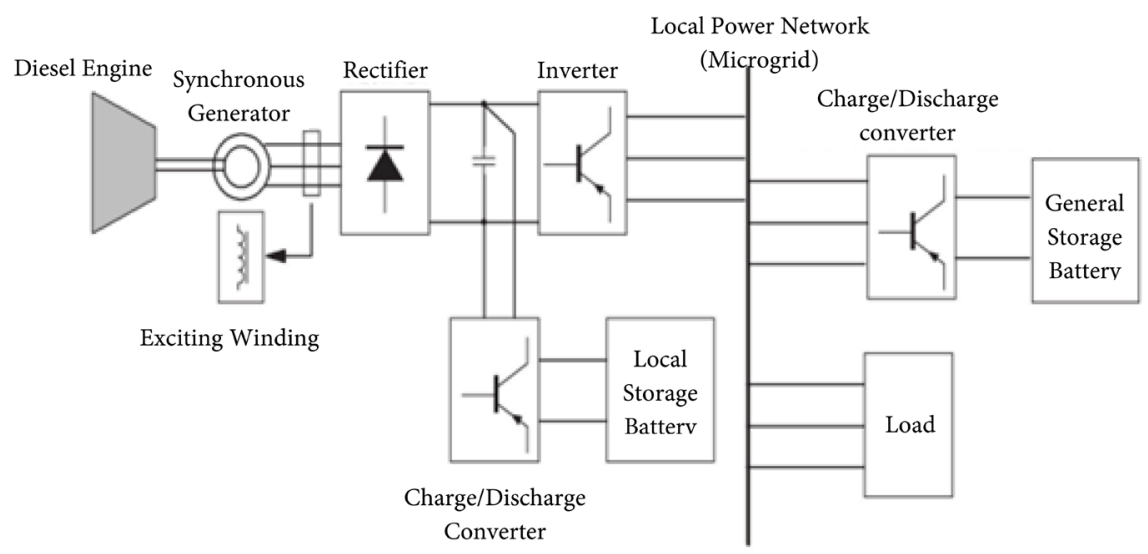

Figure 23. Typical configuration of a stand-alone Microgrid with DPG and BSS [65].

\section{Analysis of the Benefits and Limitations of the Proposed Technologies}

Each of the above-mentioned techniques has its advantages and disadvantages. To do this, we have created for each of the methodologies applied, a table summarizing the benefits and limitations of the technologies discussed in Section 2. Table 3 covers optimization solutions for DE's using Pre-treatment solutions while Table 4 covers optimization solutions for DE's using Internal and Post-treatment technologies. Finally, Table 5 covers optimization solutions applied for DPG's using electrical and mechanical technologies.

However, in order to be able to evaluate the various solutions proposed and to identify the most efficient techniques according to the application, a list of criteria can be considered by the operator such as:

- Adaptability to the diesel engine: the chosen system must be able to adapt to the engines already in place in the isolated sites or ships without having to change the internal architecture of the engines. The selected technique must be applicable over a wide range of engine and DG models.

- Efficiency of the technology: the chosen system must have a good performance. This criterion is strongly related to the amount of fuel saved and/or 
the reduction of GHG.

- Cost: The costs should be as low as possible. In fact, the capital invested is the most important decision factor for the buyer.

- Simplicity of the design: This criterion is essential for maintenance and service. The simplicity of the design improves the maintainability and reduces the operating costs.

Table 3. Benefits and limitations of the selected technologies for DE'S applying pre-treatment solutions

\begin{tabular}{|c|c|c|c|}
\hline Technology & Benefits & Limitations & References \\
\hline $\begin{array}{l}\text { Emulsified } \\
\text { Fuel }\end{array}$ & $\begin{array}{l}\text { - Allows significant } \mathrm{NO}_{\mathrm{x}} \\
\text { reduction by an amount of } 80 \%\end{array}$ & $\begin{array}{l}\text { Increase the fuel consumption } \\
\text { by } 3 \% \text { to achieve the same } \\
\text { Output }\end{array}$ & $\begin{array}{l}{[21]-[27]} \\
{[68][69]} \\
{[70]}\end{array}$ \\
\hline Methanol & $\begin{array}{l}\text { - Renewable resource } \\
\text { - Biodegradable } \\
\text { - Allows } \mathrm{NO}_{\mathrm{x}} \text { reduction by an } \\
\text { amount of } 60 \% \text { and fuel } \\
\text { consumption by } 2 \%-3 \%\end{array}$ & $\begin{array}{l}\text { - Corrosive } \\
\text { - Toxic } \\
\text { - Burns with non-luminous flame } \\
\text { - Cost }\end{array}$ & $\begin{array}{l}{[12][13]} \\
{[14][15]} \\
{[16]}\end{array}$ \\
\hline LNG & $\begin{array}{l}\text { - Has environmental benefits } \\
\text { through an average reduction } \\
\text { of } \mathrm{SO}_{\mathrm{X}}, \mathrm{NO}_{\mathrm{X}}, \mathrm{CO}_{2} \text { and } \mathrm{PM}\end{array}$ & $\begin{array}{l}\text { - Highly flammable } \\
\text { - Requires huge investments for } \\
\text { storage and installation }\end{array}$ & $\begin{array}{l}{[18][19]} \\
{[20]}\end{array}$ \\
\hline
\end{tabular}

Table 4. Benefits and limitations of the selected technologies for DE's applying internal-treatment and post-treatment solutions.

\begin{tabular}{|c|c|c|c|}
\hline Technology & Benefits & Limitations & References \\
\hline $\begin{array}{l}\text { Direct Water } \\
\text { Injection } \\
\text { (DWI) }\end{array}$ & $\begin{array}{l}\text { - Potential reduction of } \mathrm{NO}_{\mathrm{x}} \text { by } \\
\text { an amount of } 60 \% \\
\text { - Can be applied for medium } \\
\text { speed marine diesel engine }\end{array}$ & $\begin{array}{l}\text { - Increase the fuel consumption } \\
\text { by } 2 \% \text { to achieve the same } \\
\text { output } \\
\text { - Cannot be employed at high }\end{array}$ & $\begin{array}{l}{[24][26]} \\
{[27]}\end{array}$ \\
\hline Exhaust Gas & - Low operating cost & loads because it will reduce the & \\
\hline $\begin{array}{l}\text { Recirculation } \\
\text { (EGR) }\end{array}$ & $\begin{array}{l}\text { - Allows significant NOx } \\
\text { reduction by an amount of } 30 \%\end{array}$ & $\begin{array}{l}\text { peak power output } \\
\text { - Increase the creation of PM } \\
\text { - Drop in engine efficiency }\end{array}$ & {$[32]$} \\
\hline Miller Cycle & $\begin{array}{l}\text { - Increase the efficiency of the DE } \\
\text { - Allows potential reduction of } \\
\text { NOx by an amount of } 40 \%-60 \%\end{array}$ & $\begin{array}{l}\text { - High cost engine } \\
\text { - Requires more maintenance }\end{array}$ & $\begin{array}{l}{[28][29]} \\
{[30]}\end{array}$ \\
\hline $\begin{array}{l}\text { Scavenge Air } \\
\text { Temperature }\end{array}$ & $\begin{array}{l}\text { - Reduce the number and size of } \\
\text { exhaust ports } \\
\text { - Allows a potential reduction of } \\
\mathrm{NO}_{\mathrm{x}} \text { by an amount of } 60 \%\end{array}$ & $\begin{array}{l}\text { - Cylinder head complex } \\
\text { - Requires periodical maintenance }\end{array}$ & $e^{[33]}$ \\
\hline $\begin{array}{l}\text { Selective } \\
\text { Catalytic } \\
\text { Reduction } \\
\text { (SCR) }\end{array}$ & $\begin{array}{l}\text { - Potential reduction of } \mathrm{NO}_{\mathrm{x}} \text { by } \\
\text { an amount of } 95 \% \\
\text { - Relatively simple installation }\end{array}$ & $\begin{array}{l}\text { - May suffer from erosion } \\
\text { - High efficiency turbocharger } \\
\text { is required to overcome the } \\
\text { pressure drop } \\
\text { - Require space for urea storage } \\
\text { and a good surface for } \\
\text { installation }\end{array}$ & $\begin{array}{l}{[36][37]} \\
{[38]}\end{array}$ \\
\hline
\end{tabular}




\section{Continued}

\begin{tabular}{|c|c|c|c|}
\hline $\begin{array}{l}\text { Diesel } \\
\text { Particulate } \\
\text { Filter } \\
\text { (DPF) }\end{array}$ & $\begin{array}{l}\text { - Simple installation } \\
\text { - Reduces PM pollutant by } 95 \% \\
\text { and Black Carbon (BC) } \\
\text { emissions by an amount of } 99 \%\end{array}$ & $\begin{array}{l}\text { - Allows a backpressure in the } \\
\text { engine involving additional fuel } \\
\text { consumption by an amount of } \\
4 \% \\
\text { - Requires regeneration } \\
\text { techniques to remove the } \\
\text { captured particles }\end{array}$ & [39] \\
\hline $\begin{array}{l}\text { Open-Loop } \\
\text { Wet Scrubber }\end{array}$ & $\begin{array}{l}\text { - Potential reduction of SOX by } \\
\text { an amount of } 98 \% \\
\text { - Potential reduction of PM by } \\
60 \% \\
\text { - Allows the possibility to } \\
\text { continue to use the cheaper } \\
\text { bunker fuel instead of low } \\
\text { sulphur fuel }\end{array}$ & $\begin{array}{l}\text { - Subject to corrosion (seawater) } \\
\text { - Requires regular maintenance } \\
\text { - Requires additional electric } \\
\text { power source } \\
\text { - Increase fuel consumption } \\
\text { - High cost }\end{array}$ & $\begin{array}{l}{[40][41]} \\
{[42][44]}\end{array}$ \\
\hline $\begin{array}{l}\text { Closed-Loop } \\
\text { Wet Scrubber }\end{array}$ & $\begin{array}{l}\text { - Potential reduction of SOX by } \\
\text { an amount of } 98 \% \text { and PM by } \\
60 \% \\
\text { - Allows the possibility to } \\
\text { continue to use the cheaper } \\
\text { bunker fuel instead of low } \\
\text { sulphur fuel }\end{array}$ & $\begin{array}{l}\text { - Requires storage space to hold } \\
\text { wastewater and hazardous } \\
\text { chemical solutions } \\
\text { - High consumption of fresh } \\
\text { water } \\
\text { - High cost }\end{array}$ & $\begin{array}{l}{[40][41]} \\
{[42][44]}\end{array}$ \\
\hline
\end{tabular}

Table 5. Benefits and limitations of the selected technologies for DPG's optimization using electrical and mechanical technologies.

\begin{tabular}{|c|c|c|c|}
\hline Technology & Benefits & Limitations & References \\
\hline $\begin{array}{l}\text { Doubly } \\
\text { Fed-Induction } \\
\text { Generator } \\
\text { (DFIG) }\end{array}$ & $\begin{array}{l}\text { - Potential reduction of fuel } \\
\text { consumption and GHG's by } \\
\text { an amount of } 15 \%-20 \% \\
\text { - Requires a low power converter }\end{array}$ & $\begin{array}{l}\text { - Generates important harmonic } \\
\text { disturbances } \\
\text { - Very sensitive to grid faults } \\
\text { - Requires more maintenance due } \\
\text { to the presence of rotor brushes }\end{array}$ & {$[61][62]$} \\
\hline $\begin{array}{l}\text { Genset-Synchro } \\
\text { Generator }\end{array}$ & $\begin{array}{l}\text { - Potential reduction of fuel } \\
\text { consumption and GHG's by } \\
\text { an amount of } 8 \%-12 \% \\
\text { - Can be adapted or integrated } \\
\text { on existing DPG and/or Wind } \\
\text { turbine generator } \\
\text { - Possibility to maintain voltage } \\
\text { and frequency constant at the } \\
\text { output of the generator by } \\
\text { controlling only the stator speed }\end{array}$ & $\begin{array}{l}\text { - Maximum generator power is } \\
\text { limited to } 85 \% \text { - } 90 \% \text { due to the } \\
\text { presence of the compensating } \\
\text { motor } \\
\text { - Requires more maintenance due } \\
\text { to the presence of rotor brushes } \\
\text { - Harmonics level are higher by an } \\
\text { amount of } 3 \% \text { compared to a } \\
\text { standard Genset }\end{array}$ & $\begin{array}{l}{[56][57]} \\
{[58]}\end{array}$ \\
\hline N-Split DPG & $\begin{array}{l}\text { Potential reduction of fuel } \\
\text { consumption and GHG by an } \\
\text { amount of } 25 \%\end{array}$ & $\begin{array}{l}\text { - Requires a large space for } \\
\text { installation } \\
\text { - Requires more maintenance } \\
\text { - High capital costs for purchase } \\
\text { and for installation }\end{array}$ & {$[62]$} \\
\hline DPG with BSS & $\begin{array}{l}\text { - Reduction of fuel consumption } \\
\text { and GHG by an amount of 5\% } \\
\text { - Ideal for twining and } \\
\text { Hybridization systems such as } \\
\text { Solar-Diesel-BSS and } \\
\text { Wind-Diesel-BSS }\end{array}$ & $\begin{array}{l}\text { - Batteries management and cost } \\
\text { - Requires electronic converters } \\
\text { - Not suitable for cold areas }\end{array}$ & $\begin{array}{l}{[64][65]} \\
{[66][67]} \\
{[68]}\end{array}$ \\
\hline
\end{tabular}


Continued

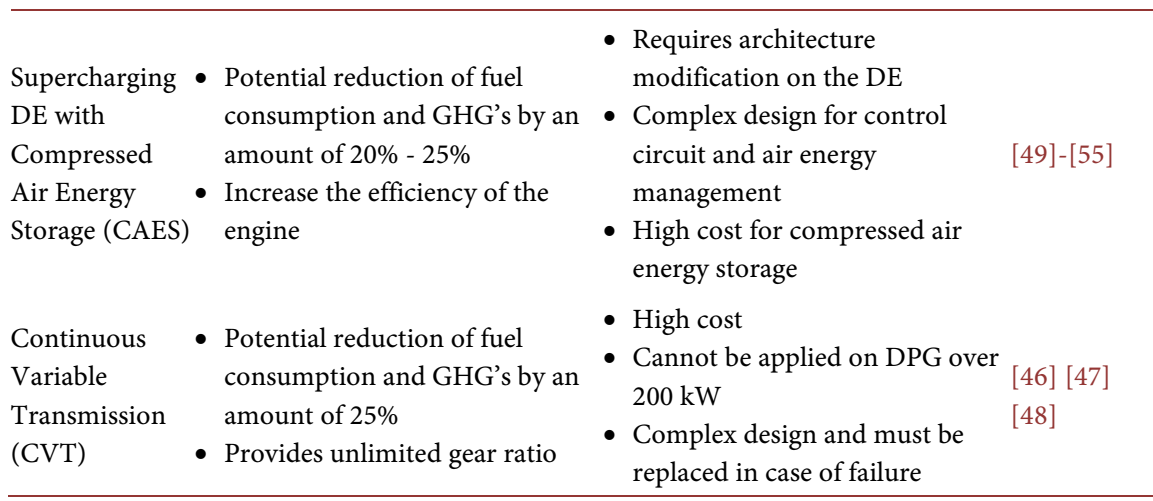

\section{Conclusion}

This paper provides an overview of the latest research developments and solutions concerning mechanical, electrical and ecological optimization in the field of DE and DPG. Internal engine modifications to reduce NOx are largely mature and are present in most new engines using mechanical and ecological solutions such as EGR, Miller cycle, SAT and using external engine methods such as SCR. Tighter SOx emission requirements are leading to sales of post-combustion gas cleaning systems (scrubber solution) as an alternative to use of (expensive) low sulphur fuel. Although one post-combustion technology (Ecospec's CSNOx) has demonstrated reduction of $\mathrm{CO}_{2}$ emissions as well as $\mathrm{NOx}$ and SOx reduction, it remains to be seen if effective commercial scale $\mathrm{CO}_{2}$ reduction is feasible. High fuel prices and emission concerns have increased the focus on utilizing liquified natural gas (LNG) as fuel oil. Nowadays, utilization of LNG as fuel is a technologically feasible solution since manufacturers have designed and developed a wide range of LNG-fueled engines. Furthermore, the use of $n$-split diesel generator instead of more commonly used single large-sized diesel generator reveals a fuel and GHG emissions saving up to $26 \%$. However, the use of variable diesel generators such as diesel-driven Genset-Synchro or DFIG can achieve interesting savings on fuel consumption and GHGs up to $15 \%$ and $20 \%$ but are subject to limit power (85\% for Genset-Synchro) and limit speed (close to synchronous speed for DFIG). In addition, advanced diesel technology and control are summarized. In the future work, the APAE technology will be tested on a $75 \mathrm{~kW} \mathrm{di-}$ esel-driven Genset-Synchro generator in order to evaluate the fuel economy, valve response time for opening and closing and effect on pollutants emissions such as NOx and soot. An automated command strategy will be proposed.

\section{Conflicts of Interest}

The authors declare no conflicts of interest regarding the publication of this paper.

\section{References}

[1] Statistics Canada (2016) Population and Dwelling Counts, for Canada, Provinces 
and Territories, 2016 and 2011 Censuses-100\% Data. https://www12.statcan.gc.ca/census-recensement/2016/dp-pd/hlt-fst/pd-pl/Table.cf $\underline{\mathrm{m}}$ ?Lang=Eng\& $\mathrm{T}=101 \& \mathrm{~S}=50 \& \mathrm{O}=\mathrm{A}$

[2] Rezkallah, M. (2016) Design and Control of Standalone and Hybrid Standalone Power Generation Systems. PhD Thesis, École de Technologie Supérieure, Montréal.

[3] Forcione, A. and Saulnier, B. (2004) Système jumelé éolien-diesel aux Îles-de-la-Madeleine (Cap-aux-Meules) Établissement de la VAN optimale. Institut de Recherche, Hydro-Québec.

[4] Hunter, R. and Elliot, G. (1994) Wind-Diesel Systems: A Guide to the Technology and Its Implementation. Cambridge University Press, Cambridge.

https://doi.org/10.1017/CBO9780511574467

[5] Maissan, J.F. (2001) Wind Power Development in Sub-Artic Conditions with Severe Rime Icing. Circumpolar Climate Change Summit and Exposition, Whitehorse, 19-21 March 2001, 1-17.

[6] Ibrahim, H. (2010) Étude et conception d'un générateur hybride d'électricité de type éolien-diesel avec élément de stockage d'air comprimé. PhD Thesis, Université du Québec à Chicoutimi, Québec. https://doi.org/10.1522/030145761

[7] Panwar, N.L., Kaushik, S.C. and Kothari, S. (2011) Role of Renewable Energy Sources in Environmental Protection: A Review. Renewable and Sustainable Energy Reviews, 15, 1513-1524. https://doi.org/10.1016/j.rser.2010.11.037

[8] Bajpai, P. and Dash, V. (2012) Hybrid Renewable Energy Systems for Power Generation in Stand-Alone Applications: A Review. Renewable and Sustainable Energy Reviews, 16, 2926-2939. https://doi.org/10.1016/j.rser.2012.02.009

[9] Dönitz, C., Vasile, I., Onder, C. and Guzzella, L. (2009) Realizing a Concept for High Efficiency and Excellent Driveability: The Downsized and Supercharged Hybrid Pneumatic Engine (No. 2009-01-1326). SAE Technical Paper. https://doi.org/10.4271/2009-01-1326

[10] International Maritime Organization (2018) Air Pollution, Energy Efficiency and Greenhouse Gas Emissions.

http://www.imo.org/en/OurWork/Environment/PollutionPrevention/AirPollution/ Pages/Default.aspx

[11] Reynolds, K.J. (2011) Exhaust Gas Cleaning Systems Selection Guide. Ship Operations Cooperative Program. The Glosten Associates, Washington DC.

[12] Heinrich, W., Marquardt, K.J. and Schaefer, A.J. (1986) Methanol as a Fuel for Commercial Vehicles (No. 861581). SAE Technical Paper. https://doi.org/10.4271/861581

[13] Allard, M. (2000) Issues Associated with Widespread Utilization of Methanol (No. 2000-01-0005). SAE Technical Paper. https://doi.org/10.4271/2000-01-0005

[14] Weimer, T., Schaber, K., Specht, M. and Bandi, A. (1996) Methanol from Atmospheric Carbon Dioxide: A Liquid Zero Emission Fuel for the Future. Energy Conversion and Management, 37, 1351-1356. https://doi.org/10.1016/0196-8904(95)00345-2

[15] Shamsul, N.S., Kamarudin, S.K., Rahman, N.A. and Kofli, N.T. (2014) An Overview on the Production of Bio-Methanol as Potential Renewable Energy. Renewable and Sustainable Energy Reviews, 33, 578-588. https://doi.org/10.1016/j.rser.2014.02.024

[16] Hikino, K. and Suzuki, T. (1989) Development of Methanol Engine with Autoignition for Low $\mathrm{NO}_{\mathrm{x}}$ Emission and Better Fuel Economy. In: SAE Transactions, SAE International, Warrendale, 639-647. 
https://doi.org/10.4271/891842

[17] Wang, W.G., Clark, N.N., Lyons, D.W., Yang, R.M., Gautam, M., Bata, R.M. and Loth, J.L. (1997) Emissions Comparisons from Alternative Fuel Buses and Diesel Buses with a Chassis Dynamometer Testing Facility. Environmental Science \& Technology, 31, 3132-3137. https://doi.org/10.1021/es9701063

[18] Elgohary, M.M., Seddiek, I.S. and Salem, A.M. (2015) Overview of Alternative Fuels with Emphasis on the Potential of Liquefied Natural Gas as Future Marine Fuel. Proceedings of the Institution of Mechanical Engineers, Part M: Journal of Engineering for the Maritime Environment, 229, 365-375. https://doi.org/10.1177/1475090214522778

[19] Levander, O. (2011) Dual Fuel Engines Latest Developments. Technical Report, Wärtsilä, Concept Design, Hamburg. https://www.stg-online.org/veranstaltungen/Ship_Efficiency_2013.html

[20] Sastre, B.L. (2017) Implementation of LNG as Marine Fuel in Current Vessels: Perspectives and Improvements on Their Environmental Efficiency. Master Thesis, Universitat Politècnica de Catalunya, Barcelona.

[21] Nilsen, O.V. (2018) LNG Regulatory Update "Best Fuel of the Future". Internationalisation Conference on LNG Project \& the Baltic Sea Region LNG Cluster, Bergen, 10-12 April 2018, 1-31.

http://www.golng.eu/files/Main/20180417/2.\%20Ole\%20Vidar\%20Nilsen\%20-\%20 DNV\%20GL.pdf

[22] Patel, N.S., Modi, M. and Patel, T. (2017) Investigation of Diesel Engine with Water Emulsifier-A Review. International Research Journal of Engineering and Technology, 4, 879-883.

[23] Vellaiyan, S. and Amirthagadeswaran, K.S. (2016) The Role of Water-in-Diesel Emulsion and Its Additives on Diesel Engine Performance and Emission Levels: A Retrospective Review. Alexandria Engineering Journal, 55, 2463-2472. https://doi.org/10.1016/j.aej.2016.07.021

[24] Kim, M., Oh, J. and Lee, C. (2018) Study on Combustion and Emission Characteristics of Marine Diesel Oil and Water-in-Oil Emulsified Marine Diesel Oil. Energies, 11, 1830. https://doi.org/10.3390/en11071830

[25] Zhou, S., Liu, Y. and Zhou, J.X. (2014) A Study on Exhaust Gas Emission Control Technology of Marine Diesel Engine. Advanced Materials Research, 864-867, 1804-1809. https://doi.org/10.4028/www.scientific.net/AMR.864-867.1804

[26] Bedford, F., Rutland, C., Dittrich, P., Raab, A. and Wirbeleit, F. (2000) Effects of Direct Water Injection on DI Diesel Engine Combustion (No. 2000-01-2938). SAE Technical Paper. https://doi.org/10.4271/2000-01-2938

[27] Wärtsilä Corporation (2006) The Engine of Industry. Wärtsilä Annual Report, Helsinki.

https://www.wartsila.com/docs/default-source/investors/financial-materials/annualreports/annual-report-2006.pdf?sfvrsn=b1b31c45_2

[28] Wang, Y., Lin, L., Roskilly, A.P., Zeng, S., Huang, J., He, Y., Yang, J., et al. (2007) An Analytic Study of Applying Miller Cycle to Reduce $\mathrm{NO}_{\mathrm{x}}$ Emission from Petrol Engine. Applied Thermal Engineering, 27, 1779-1789. https://doi.org/10.1016/j.applthermaleng.2007.01.013

[29] Kovács, D. and Eilts, P. (2015) Potentials of the Miller Cycle on HD Diesel Engines Regarding Performance Increase and Reduction of Emissions (No. 2015-24-2440). SAE Technical Paper. https://doi.org/10.4271/2015-24-2440 
[30] Goldsworthy, L. (2002) Design of Ship Engines for Reduced Emissions of Oxides of Nitrogen. Engineering a Sustainable Future Conference Proceedings, Launceston, 6 August 2002, Vol.6, 1-10.

[31] Geist, M. (1998) Sulzer RTA-8T Engines: Compact Two-Strokes for Tankers and Bulk Carriers. Technology Review, Wärtsilä NSD Switzerland Ltd., Winterthur.

[32] Kech, J., Hegner, R. and Mannle, T. (2014) Turbocharging: Key Technology for High-Performance Engines. MTU Engine Technology White Paper.

[33] Park, H.K., Ghal, S.H., Kim, B.S., Kim, K.D. and Kim, J.S. (2006) $\mathrm{NO}_{\mathrm{x}}$ Reduction of a Medium Speed Diesel Engine Using a Charge Air Moisturizer System. In: ASME 2006 Internal Combustion Engine Division Fall Technical Conference, American Society of Mechanical Engineers, New York, 25-29. https://doi.org/10.1115/ICEF2006-1548

[34] Jääskeläinen, H. and Addy Majewski, W. (2018) Heavy-Duty Diesel Engines with Aftertreatment. DieselNet Technology Guide. https://dieselnet.com/tech/engine_heavy-duty_aftertreatment.php

[35] Man Diesel Turbo (2018) Exhaust Gas Emission Control Today and Tomorrow. https://marine.mandieselturbo.com/docs/librariesprovider6/technical-papers/exhau st-gas-emission-control-today-and-tomorrow.pdf?sfvrsn $=22$

[36] Baik, J.H., Yim, S.D., Nam, I.S., Mok, Y.S., Lee, J.H., Cho, B.K. and Oh, S.H. (2004) Control of $\mathrm{NO}_{x}$ Emissions from Diesel Engine by Selective Catalytic Reduction (SCR) with Urea. Topics in Catalysis, 30, 37-41. https://doi.org/10.1023/B:TOCA.0000029725.88068.97

[37] Tersus Diesel Exhaust Fluid (2017) Selective Catalytic Reduction. How It Works, https://www.tersusdef.com/about/how-selective-catalytic-reduction-scr-works

[38] Nett Technologies Inc. (2016) BlueMax ${ }^{\mathrm{TM}}$ Selective Catalytic Reduction (SCR) System. SCR Performance.

https://www.nettinc.com/products/selective-catalytic-reduction-scr/bluemax

[39] Van Rens, G. and De Wilde, H. (2005) Pre- and After-Treatment Techniques for Diesel Engines in Inland Navigation. Technical Report in the Framework of EU Project CREATING.

[40] Andersson, K., Brynolf, S., Lindgren, J.F. and Wilewska-Bien, M. (2016) Shipping and the Environment: Improving Environmental Performance in Marine Transportation. Springer, Berlin.

[41] Ibrahim, S. (2016) Process Evaluation of a $\mathrm{SO}_{\mathrm{x}}$ and $\mathrm{NO}_{\mathrm{x}}$ Exhaust Gas Cleaning Concept for Marine Application. Chalmers University of Technology, Göteborg.

[42] University of Calgary (2018) Energy Education-Scrubber. https://energyeducation.ca/encyclopedia/Scrubber

[43] Ecospec (2015) $\mathrm{CSNO}_{\mathrm{X}}$ Emission Control. http://www.ecospec.com/marine-csnox

[44] Wolfson, R. (2012) Energy, Environment and Climate. 2nd Edition, Norton, New York.

[45] Hamilton, J.M., Negnevitsky, M., Wang, X., Tavakoli, A. and Mueller-Stoffels, M. (2017) Utilization and Optimization of Diesel Generation for Maximum Renewable Energy Integration. In: Smart Energy Grid Design for Island Countries, Springer, Cham, 21-70. https://doi.org/10.1007/978-3-319-50197-0_2

[46] Seelan, V. (2015) Analysis, Design and Application of Continuously Variable Transmission (CVT). International Journal of Engineering Research and Applications, 5, 99-105.

[47] Meiners, D. (2013) Application of Variable Speed Diesel Generator Set for Village 
Power and Wind-Diesel Applications. Report, Alaska Energy Authority, Anchorage.

[48] Kim, J., Park, F.C., Park, Y. and Shizuo, M. (2002) Design and Analysis of a Spherical Continuously Variable Transmission. Journal of Mechanical Design, 124, 21-29. https://doi.org/10.1115/1.1436487

[49] Ibrahim, H., Younès, R., Ilinca, A., Ramdenee, D., Dimitrova, M., Perron, J., Arbez, C., et al. (2011) Potential of a Hybrid Wind-Diesel-Compressed Air System for Nordic Remote Canadian Areas. Energy Procedia, 6, 795-804. https://doi.org/10.1016/j.egypro.2011.05.090

[50] Basbous, T. (2013) Hybridation pneumatique d'un moteur diesel en vue de son utilisation dans un système hybride éolien-diesel avec stockage d'énergie sous forme d'air comprimé. PhD Thesis, Université du Québec à Chicoutimi, Québec. https://doi.org/10.1522/030565288

[51] Beaulac, P. (2014) Jumelage éolien-diesel avec stockage d'air comprimé: Modélisation de la suralimentation du moteur diesel. Master of Science Thesis, Université du Québec à Rimouski, Québec.

[52] Saad, Y. (2018) Gestion optimale des systèmes hybrides pour la production de l'énergie dans les sites isolés. PhD Thesis, Université de technologie Belfort-Montbéliard, Belfort.

[53] Kang, H. and Tai, C. (2010) Demonstration of Air-Power-Assist Engine Technology for Clean Combustion and Direct Energy Recovery in Heavy Duty Application. Mack Trucks Incorporated, Detroit, MI.

[54] Foley, A. and Lobera, I.D. (2013) Impacts of Compressed Air Energy Storage Plant on an Electricity Market with a Large Renewable Energy Portfolio. Energy, 57, 85-94. https://doi.org/10.1016/j.energy.2013.04.031

[55] Ibrahim, H., Ilinca, A. and Perron, J. (2008) Energy Storage Systems-Characteristics and Comparisons. Renewable and Sustainable Energy Reviews, 12, 1221-1250. https://doi.org/10.1016/j.rser.2007.01.023

[56] Issa, M., et al. (2017) Modeling and Optimization of the Energy Production Based on Eo-Synchro Application. Power Engineer, 21, 3-9.

[57] Issa, M., et al. (2018) Optimizing the Performance of a 500kW Diesel Generator: Impact of the Eo-Synchro Concept on Fuel Consumption and Greenhouse Gases. Power Engineer, 23, 22-31.

[58] Issa, M., Fiset, J., Ibrahim, H. and Ilinca, A. (2019) Eco-Friendly Selection of Diesel Generator Based on Genset-Synchro Technology for Off-Grid Remote Area Application in the North of Quebec. Energy and Power Engineering, 11, 232-247. https://doi.org/10.4236/epe.2019.115015

[59] Koczara, W. and Iwanski, G. (2009) Fuel Saving Variable Speed Generating Set. International Conference on Clean Electrical Power, Capri, 9-11 June 2009, 22-28. https://doi.org/10.1109/ICCEP.2009.5212087

[60] Iwanski, G. and Koczara, W. (2008) Power Management in an Autonomous Adjustable Speed Large Power Diesel Gensets. Power Electronics and Motion Control Conference, Poznan, 1-3 September 2008, 2164-2169. https://doi.org/10.1109/EPEPEMC.2008.4635586

[61] Kendouli, F., Nabti, K., Abed, K. and Benalla, H. (2011) Modélisation, simulation et contrôle d'une turbine éolienne à vitesse variable basée sur la génératrice asynchrone à double alimentation. Revue des Energies Renouvelables, 14, 109-120.

[62] Ayodele, T.R., Ogunjuyigbe, A.S.O. and Akinola, O.A. (2017) N-Split Generator Model: An Approach to Reducing Fuel Consumption, LCC, $\mathrm{CO}_{2}$ Emission and 
Dump Energy in a Captive Power Environment. Sustainable Production and Consumption, 12, 193-205. https://doi.org/10.1016/j.spc.2017.07.006

[63] Voroshilov, A.N., Khristolyubova, A.I., Khristolyubov, A.A. and Kuchak, S.V. (2013) Diesel-Generator Set Working in Parallel with Electrical Energy Storage System. 14th International Conference of Young Specialists on Micro/Nanotechnologies and Electron Devices, 1-5 July 2013, 288-292.

https://doi.org/10.1109/EDM.2013.6641997

[64] Pichkalov, I. (2014) Optimal Coordinated Control of Diesel Generator and Battery Storage System of Stand-Alone Microgrid. 2nd Workshop on Advances in Information, Electronic and Electrical Engineering, Vilnius, 28-29 November 2014, 1-4. https://doi.org/10.1109/AIEEE.2014.7020331

[65] Guo, L., Fu, X., Li, X. and Wang, C. (2012) Coordinated Control of Battery Storage System and Diesel Generators in AC Island Microgrid. 7 th International Power Electronics and Motion Control Conference, Harbin, 2-5 June 2012, Vol. 1, 112-117. https://doi.org/10.1109/IPEMC.2012.6258871

[66] Shaahid, S.M. and El-Amin, I. (2009) Techno-Economic Evaluation of Off-Grid Hybrid Photovoltaic-Diesel-Battery Power Systems for Rural Electrification in Saudi Arabia-A Way Forward for Sustainable Development. Renewable and Sustainable Energy Reviews, 13, 625-633. https://doi.org/10.1016/j.rser.2007.11.017

[67] Ghasemi, A., Asrari, A., Zarif, M. and Abdelwahed, S. (2013) Techno-Economic Analysis of Stand-Alone Hybrid Photovoltaic-Diesel-Battery Systems for Rural Electrification in Eastern Part of Iran-A Step toward Sustainable Rural Development. Renewable and Sustainable Energy Reviews, 28, 456-462. https://doi.org/10.1016/j.rser.2013.08.011

[68] Bernal-Agustín, J.L. and Dufo-Lopez, R. (2009) Simulation and Optimization of Stand-Alone Hybrid Renewable Energy Systems. Renewable and Sustainable Energy Reviews, 13, 2111-2118. https://doi.org/10.1016/j.rser.2009.01.010

[69] Syu, J.-Y., Chang, Y.-Y., Tseng, C.-H., et al. (2014) Effects of Water-Emulsified Fuel on a Diesel Engine Generator's Thermal Efficiency and Exhaust. Journal of the Air \& Waste Management Association, 64, 970-978. https://doi.org/10.1080/10962247.2014.905508

[70] Vellaiyan, S. and Amirthagadeswaran, K.S. (2017) Emission Characteristics of Water-Emulsified Diesel Fuel at Optimized Engine Operation Condition. Petroleum Science and Technology, 35, 1355-1363.

https://doi.org/10.1080/10916466.2017.1330348 


\section{Nomenclature}

APAE-Air Power Assist Engine

BSS-Battery Storage System

CAES-Compressed Air Energy Storage

$\mathrm{CO}_{2}-$ Carbon dioxide

CVT-Continuous Variable Transmission

DE-Diesel Engine

DFIG-Dual Fed Induction Generator

DG-Diesel Generator

DMCC-Diesel/Methanol Compound Combustion

DPF-Diesel Particulate Filter

DPG-Diesel Power Generator

DWI-Direct Water Injection

ECA-Emission Control Area

EGR-Exhaust Gas Recirculation

EIVC-Early Intake Valve Closing

EPA-Environmental Protection Agency

GHG-Greenhouse Gas

HAM-Humid Air Moisturised

$\mathrm{HC}-\mathrm{Hydrocarbons}$

HFO-Heavy Fuel Oil

IMO-International Maritime Organization

LCC_Life Cycle Cost

LNG_Liquefied Natural Gas

MARPOL-Marine Pollution

MDO-Marine Diesel Oil

$\mathrm{NO}_{\mathrm{X}}$-Oxides of Nitrogen

PM-Particulate Matter

SAT-Scavenge Air Temperature

SCR-Selective Catalytic Reduction

$\mathrm{SO}_{\mathrm{X}}$-Sulphur Oxides

THD-Total Harmonic Distortion

VSDE_-Variable Speed Diesel Engine 